\title{
Quality Management in Asian Universities: Lessons from the European and American Universities
}

\author{
Soaib Asimiran \\ Universiti Putra Malaysia, Serdang, Malaysia \\ soaib@upm.edu.my
}

\author{
Baboucarr Njie \\ Regional Maritime University, Nungua, Accra, Ghana \\ bnjie@utg.edu.gm
}

\author{
Mahfud M. Gamar \\ Universitas Tadulako, Palu, Indonesia \\ gamarunggul@yahoo.com
}

\begin{abstract}
Quality management has taken ascendancy in the universities in particular due, inter alia, to the loss of their status as ivory towers. Hence, quality management in universities takes prominence over several other initiatives. Attention is not only drawn on whether it is primed in universities but also on its practicability and the mechanism for gauging how it is performing. The first pronouncement that comes from universities in their websites, advertisements, and banners and indeed in any policy pronouncement or at any other opportunity is how they are committed to quality, what is being done about it and the status of quality management. This paper compares the quality management in the western and American universities and what Asian countries have learnt from both. Their interaction and corresponding accountability to regulating agencies prompt them to align their existence to such needs into their higher educational frameworks.
\end{abstract}

Keywords: quality management, university, american universities, european universities, asian universities

\section{INTRODUCTION}

There is no doubt that quality and its related issues are prominent topics in today's university environment. Literature is available to describe and explain the reason for such state. Universities and student numbers have ascended to an unprecedented numbers. However, corresponding financial resources have been strained and pressures for accountability are mounting especially on public universities. Historically, quality has been in existence in universities higher education from its early inception and its present exhilaration could at best be explained as a rejuvenation from consciousness of quality matters in university education system.

This paper reviews the development of quality management in universities' environment in various continents particularly in Europe and the United States of America, and what Asian universities have learnt from them. Self-initiatives, declaration and monitoring of performance in the name of accountability are briefly discussed to show how quality has indeed been very close with the development and expansion of universities especially in the Asian countries. The emphasis is on the practices of those countries and what have been learnt from them.

\section{LITERATURE REVIEW}

\section{Historical Perspective of Quality Development}

Universities of the twentieth century is the lineal descendant of mediaeval universities of Paris and Bologna (Barnabas, 2007). Many of the universities now have tried to have similar collegial atmosphere as that of Oxford and Cambridge or any other early universities. Barnabas (2007) further explains "the fundamental organization of these mediaeval institutions is the same, and the historic commitment to maintain standards of institutional quality and accountability, particularly with regard to program review, evaluation and assessment, is unbroken". In short, regardless of the tension and pressure, quality is to be maintained and sustained (Harvey, 2006).

Hence, the endeavour to maintain quality has been present from the early period of existence of universities. The twenty first century ushered in a higher education system that transmuted from being a sanctified script that couldn't be altered or questioned to one that was looked to as a remedy to the developmental challenges judging what is invested in it and hence the alignment of its content to achieve such aim (Bridges, 2000).

The result was the creation of various quality assurance bodies at macro level by governments to supervise quality assurance efforts at the higher education institutes with the rules gradually changed from a voluntary endeavour to an obligation by rules and regulations. The present quality assurance bodies in various countries stem from such a philosophy and over time the need to harness efforts towards common frameworks prompted the formation of regional bodies all over the world which share best practices and inter alia recognize each other's qualifications. Quality management is indeed now regarded as the symbol of pride for comparison among nations (Salmi, 2009).

\section{Quality Assurance in American Higher Education}

The United States is usually quoted as having a long history of quality assurance (Rhoades \& Sporn, 2002). External quality monitoring is the method employed for quality assurance in the United States. The U.S. accreditation structure is decentralized and complex, mirroring the decentralization and complexity of American higher education (Eaton, 2011). The system of quality assurance in USA however is somewhat complex because no single institution takes charge for quality assurance as found in most other countries. Even the federal government 
has limited roles which are not beyond the general responsibilities of education and are limited to authorizing educational institutions to operate and the issuance of licenses for entry into professions. In essence, accreditation is conducted privately by organizations which are designed and recognized for such tasks.

The Commission on Accreditation (COA) which was founded in 1949 is often quoted as the first national organization to develop criteria for accreditation as well as recognize accrediting agencies in the US. In 1974, the COA merged with the Federation of Regional Accrediting Commission of Higher Education (FRACHE) to form the Council on Post -secondary Accreditation (COPA). COPA took charge for the promotion and ensuring that American post-secondary education was within acceptable standards until the end of 1993. The Commission on Recognition of Post-secondary Accreditation (CORPA) was instituted in 1994 both to replace and continue the work of COPA. COPA was again dissolved 3 years later in 1997 and gave way to the Council for Higher Education Accreditation(CHEA) and this body still continues to carry out the recognition function in the country (USDE, 2005).

The task of quality assurance through accreditation is therefore left to independent accreditation bodies. Again the accreditation bodies are various as they are regionally formed and each has a separate jurisdiction. The task of accreditation is thus "collectively accredit education in all states but work independent of each other and their procedures differ in many respects" (El-Khawas, 2001). El-Khawas further notes that overlapping accreditation responsibilities does exist especially between the work of regional agencies that monitor activities of the entire institutions and the work of program accrediting agencies that monitor and accredit specific academic programs or disciplines located within the same institutions.

Lenn (2003) identified three primary purposes of quality assurance: for assessment, for audit and for accreditation. Eaton (2011) identified the following five steps involved and leading to program or institutional accreditation:

1. Self-study. The stage where institutions or programs would prepare documented summaries of their performance using the standards set by the accrediting organizations.

2. Peer review. This is mainly an accreditation appraisal performed by academic and administrative colleagues and they mainly involve the reviewing institutions and programs immediately following the self study process.

3. Site visit. The visit of the members or representations of the accreditation organization for the actual review of the institution or program.

4. Judgment by accrediting organization. This involves the decisions or judgment of the decision making bodies of the accreditation organization or commission by affirmation of new institutions or programs, reaffirmation of existing ones or denial of accreditation for those that do not meet the criteria.
5. Periodic external review. Involves the continuous review of institutions overtime through self study programs and site visits.

In essence accreditation is a trust-based, standards-based, evidence-based, judgment-based, peer-based process (Eaton, 2011).They can be regional, national or specialized or professional but all seek regular recognition or in effect the license to operate from CHEA or USDE. Also worthy of mention is the fact that accreditation in the US is not graded with scores or letter grades. Rather it is either granted or denied on the basis of the institutions concern either meeting the accreditation criteria as laid down by the agency or falling below it and thus warranting denial.

\section{Quality Assurance in the European Universities}

During the 1980's attention significantly shifted to quality issues in higher education as a result of the global financial meltdown that affected many European countries. This was compounded by the rapid increase in student numbers in universities that emanated from the quest for massification of higher education. The dilemma was therefore the strain that was being felt by governments in national budgets as against the increase in student numbers in higher education which were two diverging state of affairs. As a result, a large number of education institutions all over Europe [saw] a progressive withdrawal of the State as the main financing body of the university system (Orsingher,2006). Over and above the state withdrawal as the main financer, the questions of quality suddenly emerged and most states started asking questions about the sustainability of the quality in higher education institutes against the rapid increase in higher education institutes, student numbers and the shrinking economic realities.

Key developments have taken place in Europe in the last three decades among which included four key declarations; The Magna Charta Universitatum 1988, The Sorbonne Declaration 1998, The Bologna Declaration 1999, The Salamanca Convention and Prague Communique 2001.

The Magna Charta Universitatum declared in 1988 espoused university autonomy and although 388 University Rectors around the globe are signatories to the declaration it was nevertheless meant to bolster the far reaching co-operation between all European nations who were at the time conscious of the pivotal role universities would be relied on to play in the changing and increasingly international society.

The Sorbonne Declaration: The Sorbonne meeting of Higher Education Ministers in Paris in 1998 was the antecedent of the Bologna Process. The declaration was dubbed "Joint declaration on harmonization of the architecture of the European higher education system" (Sorbonne declaration, 1998). It focused, inter alia, on a progressive convergence of the overall framework of degrees and cycles in an open European area for higher education, the enhancing and facilitating of student and teacher mobility and removing obstacles for mobility and 
improving recognition of degrees and academic qualifications (Sorbonne declaration, 1998).

The Bologna declaration: The bologna declaration came into effect in 1999 when 29 European Ministers in charge of higher education signed the affirmation in Bologna (Bologna Declaration, 1999). Among the intention was the adoption of a system of easily readable and comparable degrees among the European countries in order to ease employability and the international competitiveness of the European higher education system.

The Salamanca Convention and the Prague Communiqué both of which were accented to in 2001 considered quality as fundamental in the European higher education area. While the Salamanca convention viewed quality as a deep-seated building block and an underlying condition for trust, compatibility, relevance and mobility, the Prague Communiqué regarded it as a key factor in determining both the competitiveness as well as the attractiveness of European Higher Education.

While differences in terms of the organization, intention and focus of quality assurance set ups across Europe exists, most subscribe to the same system of quality assurance with common frameworks that establish generic standards which must be met to qualify for registration into them. Whereas quality evaluation is only an internal responsibility of higher education institutions in countries where no national agency exists such as Austria, Switzerland, Slovenia and the French community of Belgium, in many others there is an obligation for universities to have their own quality evaluation system and a body at national level responsible for the process such as Portugal, Spain, Germany and Iceland (ESIB).

The European Quality Assurance for Higher Education (EQAR) which was launched in 2008 serves as the umbrella of all sister organization of the same aim in Europe. It was established by the "E4 GROUP"(EQAR) which comprise the European Association for Quality Assurance in Higher Education(ENQA), the European Students Union(ESU), the European University Association(EUA) and the European Association of Institutions in Higher Education (EURASHE). EQAR provides comprehensible and objective information as regards trustworthy quality assurance agencies in the continent. Through such means it hopes to improve the general quality of the European higher education as well as encourage student mobility which would stem from trust built between higher education institutions.

\section{Focus on Quality in the United Kingdom}

The United Kingdom has had its fair share of the quality effort particularly in the 1990's. On 16 May 1991 the Government published a White Paper, Higher Education: A new framework (DES, 1991). By this time there were 1.176 million students in UK higher education, 748,000 full-time and 428,000 part-time (Government Statistical Service, 1993) mainly as result of the success of the new General certificate of Secondary Education (GCSE) in improving retention rates in post-compulsory education and governments intention to bring UK participation at par with other competing industrialized countries (Brown, 2004) and clearly the need for government to cater to the increasing number of students eligible for entry in higher education.

The 1991 whitepaper was the formal announcement of government to abolish the binary line between the existing universities and polytechnics such that the latter would attain university status. The White Paper included proposals for a new quality assurance regime which would for the first time bring the regulation of all institutions' teaching and learning activities within an overall statutory framework (Brown, 2004). This was followed by a succession of quality regimes and for the next ten years there were no fewer than three major ones among others with some scholars (Parry, 2002) even daring to say there were actually ten. In a nutshell the need for accountability of higher educational institutions which coincided with shrinking resources and the need to attract more students among competing universities all contributed immensely towards the adoption of quality assurance mechanisms among higher educational institutions in the UK.

Quality management except for the specific emphasis has in essence been present in many higher educational institutions including those of the UK as earlier alluded to. "These include the external examiner system, professional accreditation of programs, inspection of provision, quality audit of institutional processes, assessment of programs, and research assessment" (Harvey, 2005). The Quality Assurance Agency for Higher Education (QAA) a specific body established in 1997 works towards guaranteeing standards of higher education in the UK. It checks how universities and colleges maintain their academic standards and quality as well as works to regulate the entry levels to higher education programs especially for candidates without the usual entry level qualifications. Quality assurance is mainly done through institutional audit and subject reviews in the UK.

\section{Quality Assurance in Asian Higher Education}

In Asia, likewise other parts of the world, the impact of western academic models and institutions has been significant from the beginning and remains important even in contemporary period (Altbach, 1989). In fact the western academic model remains dominant worldwide (Altbach, 1989). The Case of quality assurance in Asia depicts an interesting mix of the quality assurance practices of both America and Europe. Higher education in Asia has experienced significant changes over the past two decades that consequently required changes in outlook especially in the areas of regulation and quality.

Most of the developed countries resorted to quality assurance systems especially as a means of regulation due to the rapid increase in student numbers. Similarly in Asia massive increases in student numbers, total costs of higher education, the crossborder mobility of students and graduates, and the cross-border mobility of education have all combined 
to require changes (Stella, 2011). Prominent among those changes was the need to step up quality assurance mechanisms in their wide-ranging forms from regulations, audits, and controls to accreditations.

Individual countries in the Asian region all had their own internal quality assurance systems of some sort and were gradually improving them to be at par with others with more developed quality assurance systems. Gradually external systems in the form of regional quality assurance systems started springing to light such as the Asia-Pacific Quality Network (APQN), ASEAN Quality Assurance Network (AQAN) and they serve as platforms for the exchange of ideas and innovations of good practices.

Today many governments in Asia are aware of the benefits of quality assurance strategies and besides establishing quality assurance bodies they have also instituted measures towards strengthening them .China, India, Hong Kong, Japan, Malaysia, Mongolia, Philippines, Thailand. Indonesia and Vietnam are among the countries with well establish quality management institutions in the region. As an example, in Malaysia, the Malaysian Qualification Agency (MQA) established in 2007 is specifically tasked with quality monitoring of higher education in the country.

All institutions of higher learning are expected to adhere with the requirements set up by the government and monitored by the MQA (Ministry of Higher Education Malaysia, 2006). Universities in Malaysia, particularly the public universities have well documented policies on quality assurance implementation and proper structures to oversee the quality assurance practices adhering to government policies and aspirations (Njie, Asimiran, Basri, \& Kadir, 2018).

\section{DISCUSSION}

Universities have, without a doubt, changed in great deal from how they were started. Quite apart from the rise in student numbers, an important defining moment of those changes was the destruction of the University as an ivory tower, that independent entity with no human face and only strictly operated within the circles of intellectual knowledge where it was normal for students to drop in their numbers along the educational journey without much remorse on the side of the universities.

Governments and societies rely on the universities to help produce the critical human resources needed to steer societies and countries in the directions of national development. Universities have no choice be it the public or private ones because both relied on funds generated by the public for their survival and sustainability at a time when operational costs increased drastically due to availability of much technological and physical equipment which were hitherto unavailable. That reliance no doubt comes with consequences and the most pronounced was to give in to governments and societies' priorities of producing students with the necessary intellect but also the practical skills needed to steer development of various sectors in the wider system.
Such a shift ushered in the important issue of accountability on the part of the universities to her stakeholders. From then on institutions of higher learning not only have to justify the tenets of their operation in terms of cost in the public institutions but also how much the policy pronouncements and academic promise walks the talk of producing the mold of students it vows to develop. In the private institutions, likewise, students and their sponsors have to realize the handy effects of the institution on its products, as declared, as a mark of confidence to ensure trust and nurture confidence. Above all, institutional survival is their key concerns.

The generic system of quality assurance in US would be better understood if one looks at the overall picture of each state having its own unique attributes and in most cases different sets of laws and as a result the diversity in jurisdiction in the various states but the overall aim of accountability is the same as in Europe and all other continents. On the other hand, the formation of regional quality assurance blocs in Europe and in indeed in Asia looks beyond merely creating a system for purposes of accountability. Above the accountability quest, these bodies take particular interest in the formation of a common platform for practices leading to attainment of sound academic qualifications. Indeed the formation of various quality agencies became a common platform for good practices leading to the attainment of quality culture for good practices among the Asian universities.

\section{CONCLUSION}

Quality assurance without doubt has been embed internally within the universities set ups as early as the first citadels of knowledge were created. Their mechanisms, however, were very much within the internal core of these institutions and had no business worrying about how society viewed or wanted the system to do. The monopoly at the time coupled with the elitist selection all worked in protecting the set ups. The twenty first century has been riddled with so many issues and society ultimately looks to higher education institutions among others to extend solutions.

In addition, the reliance on society and stakeholders by the universities on valuable funds for their sustenance has prompted the ultimate accountability questions by the former to prove good value for the huge amounts being invested. The result is not only the hard sell on the part of quality assurance but the development of variously models as exemplified by the American and Europe systems and the continuous struggle to harmonize and improve them as manifested by the various regional quality assurance networks particularly among the Asian universities.

\section{REFERENCES}

[1] Altbach, P. G. 1989. Twisted Roots: The Western Impact on Asian Higher Education. Higher Education, 18(1), 9-29.

[2] Njie, B., Asimiran, S., Basri, R., \& Kadir, S. A. 2018. Quality Assurance Implementation Practices in 
Selected Malaysian Public Universities. Advances in Social Science, Education and Humanities Research, Vol. $115,3^{\text {rd }}$ International Conferences on Education in Muslim Society (ICEMS 2017), p. 298-303.

[3] Barnabas, C. C. 2007. The Evolution of Quality Assurance in Higher Education Faculty Working Papers from the School of Education. Paper 13.

[4] Bridges, D. 2000. Back to the Future: The Higher Education Curriculum in the 21st Century. Cambridge Journal of Education, 30(1), 37-55.

[5] Declaration, S. J. 1998. Joint Declaration on Harmonisation of the Architecture of the European Higher Education System. The Four Ministers in Charge for France, Germany, Italy and the United Kingdom, Paris, 25.5. 1998.

[6] DES. 1991. Higher Education: A new framework, Cmnd 1541, HMSO, London.

[7] Eaton, J. S. 2011. An Overview of U.S. Accreditation. Council for Higher Education Accreditation (CHEA).

[8] El-Khawas, E. 2001. Accreditation in the USA: Origins, Development and Future Prospects. IIEP, UNESCO.

[9] Government Statistical Service. 1993. Education Statistics for the United Kingdom: 1992 edition, HMSO, London.

[10] Harvey, L. 2006. Impact of Quality Assurance: Overview of a Discussion between Representatives of External Quality Assurance Agencies. Quality in Higher Education, 12(3), 287-290.

[11] Harvey, L. 2005. History and Critique of Quality Evaluation in the UK. Quality Assurance in Education, 13(4), 263-276.

[12] Haskins, C. H. 1957. The Rise of Universities (Vol. 15). Cornell University Press.

[13] Lenn, M. P. 2003. Strengthening World Bank Support for Quality Assurance and Accreditation in Higher Education in East Asia and the Pacific. Washington, DC: Centre for Quality Assurance in International Higher Education.

[14] Ministry of Higher Education Malaysia. 2006. Report by the Committee to Study, Review and make Recommendations concerning the Development and Direction of Higher Education in Malaysia. Shah Alam: University Publication Centre (UPENA).

[15] Orsingher, C. 2006. Assessing Quality in European Higher Education Institutions Dissemination, Methods and Procedures. Physica-Verlag Heidelberg.

[16] Parry, D. 2002. Quality Assurance in Higher Education. Perspectives, 6(1), 3-7.

[17] Rhoades, G. 2002. Globally, Nationally, and Locally Patterned Changes in Higher Education. Higher Education, 43(3), 279-280.

[18] Salmi, J. 2009. The Challenge of Establishing World Class Universities. World Bank Publications. 